\title{
PENDIDIKAN MULTIKULTURAL BAGI MASYARAKAT INDONESIA YANG MAJEMUK
}

\author{
Muhiddinur Kamal \\ Dosen STAIN Bukittinggi, Sumatera Barat \\ e-mail: muhiddinur_909@yahoo.com
}

\begin{abstract}
The diversity of Indonesia is a national asset which has long been considered by the founders of this nation. It is thought that being diversity is not a barrier to realize the unity of the Republic of Indonesia. However, the current state of our nation building indicates that such a spirit has declined as conflicts among the tribes lead to unlawful acts which raise the issues of tribes, tradition or race, and religion. Education as a tool to resolve problems either as a state or a nation. As a multicultural country, Indonesia is striving to horizontal conflict which may break the unity. Multicultural education is, therefore, expected to be able to resolve the national conflicts.
\end{abstract}

Key words: multicultural, conflict, integration

\begin{abstract}
Abstrak: Kemajemukan yang ada di Indonesia merupakan suatu kekayaan bangsa. Realitas ini disadari oleh para pemimpin bangsa yang memperjuangkan kemerdekaan negeri ini. Mereka memandang bahwa kemajemukan tersebut bukanlah halangan untuk mewujudkan persatuan dan kesatuan serta untuk mewujudkan cita-cita nasional dalam wadah Negara Kesatuan Republik Indonesia. Namun, dalam kehidupan berbangsa akhirakhir ini terindikasi akan kecendrungan melemahnya semangat kebangsaan dan kesadaran sebagai bangsa yang multikultur. Indikasi ini terlihat adanya pertentangan-pertentangan antar kelompok, antar suku yang menjurus kepada perbuatan SARA. Pendidikan sebagai salah satu yang ampuh dalam mengatasi berbagai persoalan dalam kehidupan termasuk persoalan berbangsa dan bernegara. Pendidikan multikultural dengan pendekatan studi kultural mengenai pendidikan diharapkan mampu mengatasi persoalan bangsa yang rawan konflik menjadi bangsa yang kuat dalam keberagaman.
\end{abstract}

Kata Kunci: multikultural, konflik, dan integrasi.

\section{PENDAHULUAN}

Masyarakat Indonesia merupakan masyarakat majemuk (plural society), yang terdiri dari bermacam-macam suku bangsa, memeluk agama dan kepercayaan yang berbeda-beda, serta mempunyai bahasa dan corak sosial budaya ang tidak sama antara yang satu dengan yang lainnya.

Pluralitas dalam masyarakat Indonesia umumnya terjadi karena adanya proses migrasi suatu suku bangsa. Hal ini disebabkan oleh dorongan sosiokultural dan kebijakan pembangunan oleh pemerintah. Migrasi yang didorong oleh sosiokultural dapat dilihat pada budaya merantau bagi masyarakat Minangkabau, Bugis maupun suku Batak. Sedangkan migrasi yang disebabkan oleh kebijakan pembangunan, sebagaimana lazimnya terjadi pada suku bangsa Jawa, Bali dan Lombok dalam program transmigrasi. Apapun yang melatar belakangi, proses migrasi tersebut menjadi masyarakat hidup dalam pluralitas yang tentukan akan berpengaruh terhadap tatanan sosial budaya masyarakat.

Mengelola kemajemukan bukalah perkara yang mudah. Disuatu sisi, masyarakat sebagai salah satu komponen bangsa memelihara identitas dan memperjuangkan aspirasinya. Pada sisi lain, mereka juga dituntut untuk memberi andil dalam rangka memelihara kerukunan dan keutuhan bangsa.

Berbagai pertentangan mewarnai perjalanan bangsa Indonesia terutama sejak berakhirnya rezim orde baru dengan konsep sentralistis dan monokulturalnya yang dibungkus dengan kestabilan demi pembangunan. Pergantian rezim orde baru dengan era reformasi sering membuat era keterbukaan 
dari era keterkungkungan itu menjadi kebablasan sehingga terjadi demokrasi yang kebablasan tanpa kendali sebut saja demonstrasi yang anarkis, kerusuhan dll. Demikian juga halnya dengan berbagai konfli berskala besar seperti konflik di Ambon, Sambas, Sampit dan Poso dan sebagainya.

Pertentang yang berbaur SARA di atas, mengajarkan kita betapa pentingnya pendidikan multikultural pada masyarakat majemuk sebagai wujud kesadaran tentang keanekaragaman kultural, hak-hak asasi manusia serta pengurangan atau penghapusan berbagai jenis prasangka atau prejudise untuk membangun suatu kehidupan masyarakat yang adil dan maju.

\section{SIGNIFIKANSI}

Kehidupan yang damai, tentram dan sejahtera merupakan dambaan hidup hampir setiap umat manusia. Namun dambaan manusia untuk hidup yang harmoni dalam bermasyarakat itu belum sepenuhnya dapat terwujudkan sebagai akibat dari munculnya ketegangan sosial yang sering melahirkan konflik intern dan antar masyarakat apakah itu konflik suku, adat, ras ataupun agama.

Kajian mendalam mengenai pendidikan multikultural pada msyarakat majemuk kiranya sangat penting untuk dikaji, mengingat nilai-nilai kemajemukan pada pendidikan multikultural diharapkan dapat menciptakan keharmonisan dalam kehidupan. Jika kesadaran akan multkultural tidak dikaji dan nilainilai yang mendukungnya tidak dilestarikan maka tidak tertutup kemungkinan akan dapat terjadi juga konflik sosial didaerah ini sebagaimana konflik sosial yang pernah menimpa pada beberapa daerah yang memiliki masyarakat yang majemuk.

\section{RUMUSAN MASALAH}

Berdasarkan latar belakang dan signifikansi di atas maka permasalahan yang akan diungkap adalah:

1. Bagaimana hakikat multikultural dan hakikat masyarakat majemuk?

2. Bagaimanakah konsep pendidikan multikultural?

3. Bagaimanakah urgensi pendidikan multikultural di Indonesia?

\section{TUJUAN}

Bertolak dari pertanyaan di atas maka tulisan ini bertujuan untuk:

1. Mengkaji hakikat multikulturalisme dan hakikat masyarakat majemuk

2. Mengkaji konsep-konsep pendidikan multikulturalisme

3. Mengkaji urgensitas pendidikan Multikultura di Indonesia

\section{PEMBAHASAN}

\section{A. Hakikat Multikultural dan Masyarakat Majemuk}

1. Pengertian dan hakikat Multikultural.

Multikultural secara etimologis terbentuk dari kata multi yang berarti banyak dan kultur yang berarti budaya. (Tilaar: 2004). Sedangkan secara hakiki multikultural berarti pengakuan akan martabat manusia yang hidup dalam komunitasnya dengan kebudayaannya masing-masing yang unik (Choirul Mahfud: 2009). Jadi multikultural itu pengakukan akan keberadaan manusia yang beragam baik dari sisi etnis, budaya dan sebagainya. Dengan demikian dalam konsep multikultural, setiap individu merasa dihargai dan sekaligus bertanggung jawab untuk hidup bersama komunitasnya dimana berada.

Adapun Multukulturalisme dalam pandangan Irwan Abdullah (Dalam Masdar Hilmi: 2002), paham multikultural merupakan paham kesederajatan dan kesetaraan budaya- 
budaya lokal dengan tanpa mengabaikan hakhak dan eksistensi budaya yang ada. Dengan kata lain penekanan multukulturalisme adalah penekanan pada kesetaran budaya-budaya.

Multikultualisme dapat juga dipandang sebagai sebuah konsep dimana sebuah komunitas dalam konteks kebangsaan dapat mengakui keberagaman, perbedaan dan kemajemukan budaya, baik ras, suku, etnis, agama dan lain sebagainya. Sebuah konsep yang memberikan pemahaman bahwa sebuah bangsa yang plural dan majemuk adalah bangsa yang dipenuhi dengan budaya-budaya yang beragam (multikultural). Sedangkan bangsa yang multikultural adalah bangsa yang kelompok-kelompok etnik atau budaya (ethnic and cultural group) yang ada dalam hidup berdampingan secara damai dalam prinsip co exsistensi yang ditandai oleh kesediaan hidup berdampingan dengan budaya lain.

Multikultural dalam kehidupan pada dasarnya merupakan suatu modal besar dalam membangun suatu peradaban dan perkembangan bangsa karena dengan keragaman suatu aset bangsa untuk membangun suatu kekuatan (Masdar Hilmy: 2003). Fakta sosial yang terjadi juga menunjukkan bahwa fenomena keragaman tersebut terjadi sebaliknya. Keragaman budaya telah memberi sumbangan terbesar pula bagi munculnya ketegangan dan konflik, sehingga tidak pelak lagi bahwa multikultural yang seharusnya menjadi modal sosial (social capital), justru menjadi kontraproduktif bagi penciptaan tatanan kehidupan yang damai, harmoni dan toleran.

Kondisi masyarakat atau bangsa yang multikultural dapat diibaratkan sebagai pedang bermata ganda, disatu sisi merupakan sebagai modal besar yang bisa menghasilkan energi positif, namun disisi lain jika keragaman itu tidak bisa dikelola dengan baik dapat menjadi suatu ledakan yang bisa menghancurkan sendisendi pilar-pilar kebangsaan. Ledakan destruktif itu bisa terjadi jika nalar masyarakat masyarakat masih terkooptasi oleh logosentrisme tafsir hegemonik yang sarat akan prasangka, kecurigaan, kebencian dan reduksi terhadap kelompok yang berada diluar dirinya (the other). Akibat dari hal tersebut, ikatanikatan sosial (social bond) melalui kolektivitas dan kerjasama hanya berlaku di dalam kelompoknya (in group) tetapi tidak berlaku bagi mereka pada kelompok lain (other group).

Gagasan multikulturalisme dinilai sebagai gerakan yang mengakomodir kesetaraan dalam perbedaan dan dipandang sebuah konsep yang mampu meredam konflik vertikal dan horizontal dalam masyarakat yang heterogen di mana tuntutan akan pengakuan atas eksistensi dan keunikan budaya kelompok etnis sangat lumrah terjadi. Masyarakat multikultural dirancang mampu memberikan ruang yang luas bagi berbagai identitas kelompok untuk melaksanakan kehidupan secara otonom. Dengan demikian, multikulturalisme, diharapkan mampu menciptakan suatu sistem budaya (culture system), dan tatanan sosial yang mapan dalam kehidupan masyarakat yang akan menjadi pilar kedamaian.

Parekh (Dalam Choirul Mahfud: 2009) menjelaskan lima macam konsep multikultural sebagai pandangan dunia yang kemudian diwujudkan dalam Politic of Recognition yaitu

a. Multikulturalisme isolasionis, yang mengacu kepada masyarakat dimana berbagai kelompok kultural menjalankan hidup secara otonom dan terlibat dalam interaksi yang hanya minimal satu sama lain.

b. Multukulturalisme akomodatif, masyarakat plural yang memiliki kultur dominan, yang membuat penyesuaian dan akomodasi bagi kebutuhan kultural kaum minoritas.

c. Multikultural otomatis, yakni masyarakat plural dimana kelompok-kelompok kultural utama berusaha mewujudkan kesetaraan (equality), dengan budaya dominan dan mengangankan kehidupan yang otonom dalam kerangka politik yang secara kolektif dapat diterima. Kepedulian kelompok-kelompok kultural terakhir ini adalah untuk mempertahankan cara hidup 
mereka, yang memiliki cara hidup yang sama dengan kelompok dominan. Mereka menentang kelompok kultural dominan dan berusaha menciptakan suatu masyarakat dimana setiap kelompok dapat eksis sebagai mitra sejajar.

d. Multikulturalisme kritikal atau interaktif, yakni masyarakat plural dimana kelompokkelompok tidak terlalu peduli dengan kehidupan plural otonom, tetapi lebih menuntut penciptaan kultur kolektif yang mencerminkan dan menegaskan perspektif-perspektif distingtif.

e. Multikultural Kosmopolitan, yaitu paham yang berusaha menghapus batas-batas kultural sama sekali untuk menciptakan sebuah masyarakat dimana setiap individu tidak lagi terikat kepada budaya tertentu.

Multikultural dalam sebuah komunitas besar (bangsa) merupakan sebuah keniscayaan yang tidak bisa dielakkan karena kebudayaan yang beragam suatu bangsa pada hakikatnya adalah keyataan yang majemuk atau pluralistik. Sebuah bangsa tidak akan berkembang apabila tingkat pluralistiknya kecil. Begitu pula dengan sebuah bangsa yang besar jumlah kebudayaannya, akan menjadi kerdil apabila ditekan secara institusional.

Tekanan institusi yang menekan akan kemajemukan budaya multikultural akan merusak nilai-nilai budaya yang ada dalam budaya itu. Hal ini terlihat jelas ketika politik mono-kultural yang diterapkan oleh orde baru atas nama stabilitas untuk developmentalism menghancurkan local cultural geniuse seperti nagari yang ada di Sumatera Barat yang sarat dengan nilai egaliter, mandiri dan demokratis. Walaupun sekarang masyarakat telah kembali kepada pemerintahan nagari namun karena penghapusan sistem pemerintahan ini pada masa orde baru yang cukup lama memberi pengaruh yang cukup besar terhadap pelestarian nilai-nilai local yang ada di Sumatera Barat.

Pemaksaan pada konsep monokultural pada masa orde baru juga berdampak terhadap pada perpecahan dan tindakan-tindakan yang mengarah kepada anarki ketika pengakuan identitas dirinya terhambat seperti hilangnya tradisi "pela gandong" yang mengakibatkan perpecahan di Ambon. Padahal local genius berfungsi sebagai early warning system.

Sistem atau sosio-kultural yang local pada dasarnya merupakan kekayaan kultural yang tidak ternilai harganya bukan hanya bagi masyarakatnya sendiri, tetapi juga bagi masyarakat-masyarakat lain.

Multikultural sebagai keragaman dalam kehidupan bermasyarakat dan berbangsa jika diwarnai oleh sikap toleran tanpa menimbulkan gesekan yang berarti dan membahayakan dan mampu mengadopsinya ke dalam struktur sosial menjadi kekuatan bagi masyarakat dan bangsa dalam membangun peradaban. Sejarah telah mencatat bahwa bangsa-bangsa yang mampu mengelola dan memenej multikultural dengan baik dengan menjadi bangsa besar, sebut saja zaman kemajuan peraban Islam pada masa klasik dan kemajuan Amerika maupun Kanada sekarang ini sebagai manifes dari pengelolaan multikultural.

Secara sederhana dapat disimpulkan bahwa multikultural sebagai sebuah konsep dimana sebuah komunitas dalam konteks kebangsaan dapat mengakui keberagaman, kemajemukan budaya, baik rasa, suku, etnis, agama dan sebagainya. Sebuah konsep yang memberikan pemahaman bahwa sebuah bangsa yang plural dan majemuk adalah bangsa-bangsa yang dipenuhi dengan budayabudaya yang beragam (multikultural).

\section{Masyarakat Majemuk}

Masyarakat majemuk menurut Fedyani (1986) adalah keaneragaman penyusunan yakni dari suku bangsa, agama dan golongangolongan sosial lainnya dengan ciri yang nyata adalah kecendrungan yang kuat memegang identitas golongan sosial masing-masing. Orientasi yang kuat ke dalam golongan sendiri merupakan isyarat mengenai pekanya hubungan antar golongan sosial dalam masyarakat. Orientasi kuat ke dalam tersebut merupakan faktor yang memperkuat batas sosial dan perbedaan. Agar tercipta integrasi 
dalam masyarakat majemuk maka perlu tercipta sejumlah pranata-pranata yang mengikat golongan sosial sehingga warga dapat mengidentifikasikan dirinya pada ciri yang juga dimiliki oleh warga lainnya.

Karakteristik masyarakat majemuk dalam pandangan Piere L Van den Berg (dalam Nasikun: 1995) antara lain:

a. Terjadinya segmentasi ke dalam bentuk kelompok-kelompok yang seringkali menimbulkan sub kebudayaan yang berbeda satu sama lainnya.

b. Memiliki struktur yang terbagi-bagi ke dalam lembaga-lembaga yang bersifat non komplementer

c. Kurang mengembangkan konsensus di antara para anggotanya terhadap nilai-nilai yang bersifat dasar

d. Secara relatif seringkali mengalami konflik-konflik diantara satu kelompok dengan kelompok lainnya.

e. Secara relatif integrasi sosial tumbuh di atas paksaan (coercion) dan ketergantungan dalam bidang ekonomi

f. Dominasi politik oleh satu kelompok kepada kelompok yang lain

Masyarakat majemuk dalam skala tertentu dapat dipandang sebagai aset kekayaan bangsa yang dapat memberikan kontribusi positif bagi timbulnya persaingan secara sehat. Namun dalam keadaan tertentu, masyarakat majemuk tidak hanya dipandang sebagai perbedaan belaka, tetapi sebagai suatu pertentangan atau konflik di tengah-tengah masyarakat.

\section{B. Konsep Pendidikan Multikultural}

\section{Hakikat Pendidikan Multikultural}

Pengertian pendidikan multikultural dapat meminjam pendapat dari Anderson dan Cusher (1994: 320), bahwa pendidikan multikultural dapat diartikan sebagai pendidikan mengenai keragaman kebudayaan. James
Banks (1993:3) mendefinisikan pendidikan multikultural sebagai pendidikan untuk people of color, artinya, pendidikan multikultural ingin mengeksplorasi perbedaan sebagai keniscayaan.

Hilda Hernandez mengartikan dalam bukunya Multicultural Education: A Teacher Guide to Linking Context, Process and Content menjelaskan bahwa pendidikan pendidikan multikultural sebagai perspektif yang mengakui realitas politik, sosial, dan ekonomi yang dialami oleh masing-masing individu dalam pertemuan manusia yang kompleks dan baragam secara kultural secara kultur dan merefleksikan pentingnya budaya, ras, dan gender, etnisitas, agama, status sosial, ekonomi dll.

Sejalan dengan hal di atas, Muhaemin el Ma'hady berpendapat, bahwa secara sederhana pendidikan multikultural dapat diartikan sebagai pendidikan tentang keragaman kebudayaan dalam merespon perubahan demografis dan kultural lingkungan masyarakat tertentu atau bahkan dunia global secara keseluruhan. Hal senada juga dijelaskan oleh Paulo Freire seorang pakar pendidikan kebebasan yang menyatakan bahwa pendidikan multikultural sebagai solusi untuk mengatasi perilaku sebagian orang terdidik yang menjadikan pendidikan sebagai "menara gading" yang berusaha menjauhi realitas sosial dan budaya.

Pendidikan multikultural dalam pandangan James Bank (1994) memiliki beberapa dimensi yang saling berkaitan satu sama lain beberapa dimensi yang saling berkaitan satu dengan yang lainnya yaitu:

a. Content Integration; yaitu mengintegrasikan berbagai budaya dan kelompok untuk mengilustrasikan konsep mendasar, generalisasi dan teori dalam mata pelajaran/disiplin ilmu.

b. The Knowledge construction process, yaitu membawa siswa untuk memahami implikasi budaya ke dalam sebuah mata pelajaran (displin). 
c. An Equity Paedagogy; menyesuaikan metode pengajaran dengan metode pengajaran dengan cara belajar siswa yang beragam, baik dari segi ras, budaya (culture) ataupun sosial.

d. Prejudice reduction; yaitu mengidentifikasi karakteristik ras siswa dan menentukan metode pengajaran mereka.

Sedangkan HAR Tilaar berpendapat multikultural berawal dari berkembangnya gagasan dan kesadaran tentang "interkulturalisme". Kemunculan interkulturalisme terkait dengan perkembangan politik internasional menyangkut HAM, kemerdekaan dan kolonialisme dan diskriminasi rasial serta juga meningkatnya pluralitas (keberagaman).

Fokus pendidikan multikutural bukan semata-mata diarahkan kepada rasial, agama dan kultural domain atau mainstream. Fokus seperti ini pernah menjadi tekanan pada pendidikan interkultural yang menekankan peningkatan pemahaman dan toleransi individu-individu yang berasal dari kelompok minoritas terhadap mainstream yang dominan, yang pada akhirnya menyebabkan orang-orang dari kelompok minoritas terintegrasi ke dalam masyarakat mainstream.

\section{Pendekatan Pendidikan Multikultural}

Adapun pendekatan dalam pendidikan multikultural yang dikembangkan oleh beberapa negara menurut Choirul Mahfud (2009) antara lain:

a. Pendidikan mengenai perbedaan kebudayaan

b. Pendidikan mengenai perbedaan pemahaman kebudayaan

c. Pendidikan bagi plularisme kebudayaan

d. Pendidikan multikultural sebagai pengalaman moral

Men-design pendidikan multikultural dalam tatanan masyarakat bukan sesuatu yang mudah apalagi jika dihadapkan pada masyarakat majemuk yang ditopang oleh berbagai ras. Oleh karena dalam memahami pendidikan multikultural perlu pemahaman mendalam terhadap masyarakat. Pemahaman terhadap masyarakat secara garis besar:

a. Masyarakat adalah dinamis dan selalu berkembang dan tidak ada dengan sendirinya.

b. Masyarakat bergantung pada upaya setiap individu untuk memenuhi kebutuhan melalui hubungan dengan inividu lain yang berupaya memenuhi kebutuhan masingmasing.

c. Individu-individu dalam berinteraksi dan berupaya bersama guna memenuhi kebutuhan, melakukan penataan terhadap upaya tersebut dengan jalan yang disebut dengan tantangan sosial.

d. Setiap masyarakat bertanggung jawab atas pembentukan pola tingkah laku antara individu dan komunitas yang membentuk masyarakat.

e. Pertumbuhan individu dalam komunitas, keterkaitan dan perkembangannya dalam bingkai yang menuntunnya untuk bertanggung jawab terhadap tingkah laku. (Chairul Mahfud: 2009).

Dengan demikian pendekatan dalam pendidikan multikultural adalah pendekatan kemasyarakatan. Oleh sebab itu, dalam pendidikan multikultural, maka anggota masyarakat memiliki peran dan tanggung jawab moral terhadap terlaksananya program pendidikan multikultural. Hal ini disebabkan adanya hubungan timbal balik antara masyarakat dan pendidikan. Masyarakat memiliki peran dan pengaruh yang besar terhadap perkembangan intelektual dan kepribadian individu peserta didik. Keberadaan masyarakat dalam pendidikan multikultural merupakan laboratorium dan sumber makro yang penuh alternatif untuk memperkaya pelaksanaan pendidikan berbasis multikultural. 
Masyarakat dalam keberadaannya seba-gai laboratorium dan sumber makro dalam pendidikan juga menyangkut terhadap pekembangan sikap seseorang dalam kaitannya dengan kebudayaan-kebudayaan yang berkembang di masyarakat. James Bank mengemukakan beberapa tipologi sikap seseorang terhadap cultural identity yang erat kaitannya dengan budaya yang ada disekeliling manusia itu berada dan menbentuk kepribadian seseorang tersebut. Adapun tipologi itu adalah:

1) Ethnic Psychological capacity; dimana pada tingkat ini, seseorang masih terperangkap dalam streotipe kelompoknya sendiri. Sikap kefanatikan yang luar biasa terhadap budaya sendiri dan memandang budaya lainnya inferior.

2) Ethnic Encapsulation; dimana pribadi pribadi terperangkap dalam kapsul kebudayaannya sendiri dan terpisah dari budaya lain. Sikap ini biasanya mempunyai perkiraan bahwa hanya nilainilai budayanya sendiri yang paling baik dan paling tinggi, dan biasanya bersikap curiga terhadap budaya atau bangsa lain.

3) Ethnic identifities clarification; dimana pribadi macam ini mengembangkan sikapnya yang positif terhadap budayanya sendiri dan menunjukkan sikap menerima dan memberikan jawaban positif kepada budaya-budaya lainnya.

4) The Ethnicity; dimana pribadi ini menunjukkan sikap yang menyenangkan terhadap budaya yang datang dari ethnis lain, seperti budayanya sendiri.

5) Multicultural Ethnicity; dimana pribadi ini menunjukkan sikap yang mendalam dalam menghayati kebudayaan lain di lingkungan masyarakat bangsanya.

6) Globalism; dimana pribadi ini dapat menerima di berbagai jenis budaya dan bangsa lain. Meraka dapat bergaul secara internasional dan mengembangkan keseimbangan keterikatannya dengan budaya bangsa dan budaya global.

\section{Urgensitas Pendidikan Multikultural di Indonesia}

Indonesia sebagai negara yang penuh dengan keanekaragaman, baik suku bangsa, agama, adat istiadat dan budaya. Kekayaan bangsa sebagai modal besar ini akan dapat terwujud masyarakat yang multikultural, apabila warganya dapat hidup berdampingan, toleran dan saling menghargai. Nilai budaya tersebut jangan hanya sebatas wacana, tetapi harus sebagai patokan penilaian dan pedoman etika dan moral dalam bertindak yang benar dan pantas bagi orang Indonesia.

Dalam masyarakat majemuk seperti Indonesia, pengelolan terhadap keragaman sangat urgen untuk dikaji dan diterapkan karena tanpa pengelolaan yang baik terhadap keragaman ini maka keragaman yang sedianya sebagai modal besar dalam pembangunan akan berubah menjadi racun yang siap memporak porandakan bangsa ini hancur berkepingkeping.

Urgensitas pendidikan multikultural di Indonesia dapat di urai kepada tiga garis besar: 1. Sebagai sarana alternatif pemecahan
masalah

Spektrum kultur masyarakat Indonesia yang amat beragam menjadi tantangan menjadi tantangan bagi dunia pendidikan guna mengolah perbedaan tersebut menjadi suatu aset, bukan sebagai sumber perpecahan. Pendidikan multikultural di Indonesia memiliki dua tanggung jawab besar; menyiapkan bangsa Indonesia untuk siap menghadapi arus budaya luar di era globalisasi, dan menyatukan bangsa yang terdiri dari bermacam ragam budaya.

Penyelenggaraan pendidikan multikultural di dunia pendidikan diyakini dapat menjadi solusi nyata bagi konflik dan disharmonisasi yang terjadi di tengah-tengah masyarakat, khususnya yang kerap terjadi di Indonesia. Dalam arti kata bahwa pendidikan multikultural dapat menjadi sarana alternatif pemecahan konflik sosial budaya.

Pendidikan multikultural dipandang suatu yang urgen bagi bangsa Indonesia karna umumnya masyarakat justru mengetahui dalam mengenai streotip suatu bangsa 
dibandingkan mengenal apa yang sebenarnya dimiliki bangsa tersebut. Padahal dalam pendidikan multikultural, memahami makna dibalik realitas budaya suatu suku bangsa merupakan hal yang esensial.

Perubahan yang diharapkan dalam pembelajaran dalam konteks pendidikan multikultural bukan terletak pada justifikasi angka yang berorientasi kognitif sebagaimana lazimnya penilaian keberhasilan pendidikan. Namun terletak pada terciptanya kondisi yang nyaman, damai dan toleran yang keragaman.

\section{Supaya siswa tidak tercerabut dari akar budayanya}

Era globalisai yang terjadi saat ini, selain memberikan banyak memberi banyak kemudahan dalam kehidupan dengan hadir IPTEK namun dibalik itu pertemuan antar budaya juga memberikan ancaman bagi generasi muda. Untuk menyikapi realitas global tersebut, siswa hendaknya diberi penyadaran akan pengetahuan yang beragam, sehingga mereka memiliki kompetensi yang luas akan pengetahuan global, termasuk aspek kebudayaan.

HAR Tilaar berpendapat bahwa pendidikan multikultural menjadi suatu tuntutan untuk membangun Indonesia baru dengan mengenali beragam budaya kepada siswa dan memperkokoh pemahaman siswa terhadap budayanya sehingga tidak tercerabut dari akarnya sebagai dampak dari era globalisasi.

\section{Sebagai Landasan Pengembangan Kuri- kulum}

Pendidikan multikultural sebagai landasan pengembangan kurikulum menjadi sangat penting karena kurikulum sebagai titik tolak dalam proses pembelajaran.

Pengembangan kurikulum dengan pendekatan multikultural antara lain:

a. Filosofi kurikulum yang lebih sesuai dengan tujuan, visi dan misi serta fungsi setiap jenjang pendidikan bukan berdasarkan keseragaman yang diatur dari pusat.

b. Pembelajaran yang berbasis proses bukan berbasis materi.

c. Teori belajar yang digunakan memperhatikan aspek keragaman sosial dan menempatkan siswa sebagai anggota aktif masyarakat, bangsa dan dunia.

d. Evaluasi yang digunakan meliputi keseluruhan aspek kemampuan dan kepribadian peserta didik bukan hanya penguasaan materi semata.

Dari paparan di atas dapat dipahami bahwa kedudukan kebudayaan dalam pengembangan kurikulum sangat penting mengingat perkembangan pertumbuhan dan perkembangan peserta didik tidak bisa dilepaskan dari aspek sosial budaya dimana mereka berada. Oleh karena pemikiran aspek sosial budaya yang beragam (pendidikan multikultural) perlu menjadi perhatian dalam pengembangan pendidikan.

\section{SIMPULAN}

Multikultural sebagai sebuah konsep dimana sebuah komunitas dalam konteks kebangsan dapat mengakui keberagaman, perbedaan dan kemajemukan budaya, baik ras, suku, etnis maupun agama. Pendidikan multikultural memberikan pemahaman bahwa sebuah bangsa yang plural dan majemuk adalah bangsa yang dipenuhi dengan budayabudaya yang beragam (multikultural).

Gagasan pendidikan multikultural dinilai sebagai gagasan yang mengakomodasi kesetaraan dalam perbedaan dianggap mampu meredam konflik vertikal dan horizontal dalam masyarakat yang heterogen dimana tuntutan akan akan pengakuan dan eksistensi dan keunikan budaya kelompok lumrah terjadi. 
Signifikansi pendidikan multikultural di Indonesia adalah sebagai sarana pemecahan masalah konflik yang siap mengintai kapan saja dan dimana saja, pendidikan multikultural juga sebagai pembinaan siswa agar tidak tercerabut dari akar budayanya.

\section{DAFTAR RUJUKAN}

Ahmadi, Abu, 1991. Sosiologi Pendidikan. Jakarta: Rineka Cipta

Azra, Azyumardi, 2002. Identitas dan Krisis Budaya Membangun Multikulturalisme Indonesia. Dalam http://kongres Budpar. go.id

Baidhawy, Zakiuddin, 2004. Humanitas dalam Pendidikan Multikultural. www://suara pembaruan.com

Banks A. James. 1990. Teaching Strategies For The Social Studies. New York: Longman.

Hilmy, Masdar, 2003. Menggagas Pendidikan Berbasis Multikulturalisme. Ulumuna,VII, 12 9Juli-Desember)

Jary, David \& Julia Jary. 1991. Multiculturalism. New York: Dictionari of Sosiology

Mahfud, Choirul, 2004. Menggagas Pendidikan Multikultural. Surabaya: Radar Surabaya 4 November 